Meta

Journal des traducteurs

Translators' Journal

\title{
A Framework for the Identification and Strategic Development of Translation Specialisms
}

\section{Jody Byrne}

Volume 59, numéro 1, avril 2014

URI : https://id.erudit.org/iderudit/1026473ar

DOI : https://doi.org/10.7202/1026473ar

Aller au sommaire du numéro

Éditeur(s)

Les Presses de l’Université de Montréal

ISSN

0026-0452 (imprimé)

1492-1421 (numérique)

Découvrir la revue

Citer cet article

Byrne, J. (2014). A Framework for the Identification and Strategic Development of Translation Specialisms. Meta, 59(1), 124-139.

https://doi.org/10.7202/1026473ar
Résumé de l'article

Le présent article a pour but d'explorer les difficultés rencontrées par les traducteurs récemment diplômés qui doivent déterminer et consolider leurs domaines de spécialité. S'appuyant sur une enquête qui recense les procédures de recrutement des agences de traduction, l'article illustre comment, au moment de poser leur candidature auprès des agences, les traducteurs indépendants doivent être en mesure de cerner et de décrire leurs domaines de spécialité de façon très détaillée. Les difficultés que cela présente pour les jeunes diplômés sont ensuite exposées. Après avoir examiné la diversité des mots utilisés pour répertorier les spécialités de traduction et évalué le besoin de préparer les étudiants pour leur activité professionnelle future, nous proposons un cadre de travail qui a pour objet d'aider les étudiants et les jeunes diplômés tant à déterminer et à décrire leurs spécialités qu’à en acquérir de nouvelles. Enfin, l'article explique comment ce cadre de travail peut être incorporé aux programmes de formation des traducteurs par le recours à une forme de planification de développement personnel.
Ce document est protégé par la loi sur le droit d'auteur. L'utilisation des services d’Érudit (y compris la reproduction) est assujettie à sa politique d'utilisation que vous pouvez consulter en ligne.

https://apropos.erudit.org/fr/usagers/politique-dutilisation/ 


\title{
ÉTUDES ET PROSPECTIVES
}

\section{A Framework for the Identification and Strategic Development of Translation Specialisms}

\author{
JODY BYRNE \\ Irish Translators' \& Interpreters' Association, Dublin, Ireland \\ research@jodybyrne.com
}

\section{RÉSUMÉ}

Le présent article a pour but d'explorer les difficultés rencontrées par les traducteurs récemment diplômés qui doivent déterminer et consolider leurs domaines de spécialité. S'appuyant sur une enquête qui recense les procédures de recrutement des agences de traduction, l'article illustre comment, au moment de poser leur candidature auprès des agences, les traducteurs indépendants doivent être en mesure de cerner et de décrire leurs domaines de spécialité de façon très détaillée. Les difficultés que cela présente pour les jeunes diplômés sont ensuite exposées. Après avoir examiné la diversité des mots utilisés pour répertorier les spécialités de traduction et évalué le besoin de préparer les étudiants pour leur activité professionnelle future, nous proposons un cadre de travail qui a pour objet d'aider les étudiants et les jeunes diplômés tant à déterminer et à décrire leurs spécialités qu'à en acquérir de nouvelles. Enfin, l'article explique comment ce cadre de travail peut être incorporé aux programmes de formation des traducteurs par le recours à une forme de planification de développement personnel.

\section{ABSTRACT}

The purpose of this paper is to explore the challenges facing newly qualified translators in identifying and developing their translation specialisms. By means of a survey of translation agencies' recruitment processes, the paper illustrates the need for freelance translators to be able to identify and describe their specialisms in a high level of detail when applying for work with translation agencies. The difficulties this presents to newly qualified translators are then highlighted. After considering the variety of terms used to classify translation specialisms and the need to prepare students for industry, this paper proposes a framework for the purpose of helping students and newly qualified translators to identify and describe their specialisms as well as develop new ones. The paper concludes by describing how the framework can be incorporated into translator training programmes using a form of Personal Development Planning.

\section{MOTS-CLÉS/KEYWORDS}

formation, spécialités, emploi, cadre de travail, planification du développement personnel training, specialisms, employment, framework, Personal Development Planning 
Every translator specialises sooner or later, not only because no one can pretend to know everything but, more importantly, because it pays to specialise. (Gouadec 2007: 91)

\section{Introduction}

The translation industry is a large and well-funded industry. With the global language services industry estimated to be worth $\$ 25$ billion by 2013 (Beninatto and Kelly 2009) ${ }^{1}$, it is clear that there is plenty of work for translators. However, given that the overwhelming majority of translators are self-employed freelancers - some $80 \%$ in the EU according to Boucau (2005: 28) - the level of competition among translators for a share of this business is intense and likely to intensify.

The challenge for freelance translators is not simply one of producing high quality translations, quickly and cost-effectively. Rather, they must actively generate work for themselves. To do this, they must identify which specific areas are in demand, and then ensure that they stand out from the countless other translators around the world who are all competing for the same work. Although as a whole, translation represents a broad and varied global market, demand is nevertheless focused in specific areas with technology accounting for approximately $60 \%$ of the total demand for language services (Boucau 2005: 28).

The key to successfully gaining a financially secure foothold in the translation industry is developing the right specialisms to meet the demands of the market. As the previous statistics show, the majority of work falls into the general category of technology, which covers a vast array of specialist topics and knowledge areas. This makes the process of finding work all the more challenging.

At the start of their careers, many translators do not have a clearly defined set of specialisms and may not have the necessary expertise in particular subject areas. This makes the already demanding process of finding work all the more difficult (Byrne 2012: 42). Similarly, early-career translators may find the terminology they are expected to use to describe their specialisms both daunting and confusing. The purpose of this paper is to highlight the challenges facing novice translators when they begin their search for work and continue to develop their careers. The paper will examine the process by which translators find work and identify the vast range of specialisms that are presented to translators as part of recruitment processes. Against this background, the paper will present a framework that can be used to identify and categorise existing specialisms and assist translators in developing new specialisms. The paper will conclude by discussing how the framework can be incorporated into training programmes.

\section{The Freelance Application Process}

For both experienced and novice translators alike, translation assignments can come from one or more of the following sources:

1) direct contact with clients;

2) translation agencies acting on behalf of clients.

The process of cultivating a base of direct clients requires a considerable amount of marketing and networking and it can take some time before translators see any 
returns on their efforts. For this reason, working with agencies is likely to be the first avenue explored by newly qualified translators, and it is for this reason that it forms the focus of this paper. Indeed, for many translators, working with translation agencies is the preferred option, as it relieves them of the responsibility for identifying, contacting and winning new clients. In return for somewhat lower rates, the translator does not have to engage in quite the same level of work to generate a steady flow of assignments. But in order to get work from translation agencies, translators need to ensure that they are added to those agencies' databases of translators. However, with the number of freelance translators worldwide far outstripping the number of translation agencies, applications need to be clear, concise and informative.

\subsection{Recruiting Freelance Translators}

When applying to work with an agency, translators have to submit some form of application providing details of their education, experience, rates, availability and various other details (see Lindemuth Bodeux 2001, for example). Additionally, translators need to provide details of their rates and specialisms. This allows translators to be selected according to the budget available for a particular project and provides a mechanism for agencies to select translators with the necessary subject knowledge.

This is confirmed by a survey of translation agency websites carried out for the purposes of this paper, which examined the procedures used by translation agencies to recruit freelance translators. One hundred translation agencies were selected at random by means of a simple search for the phrase "translation agency" using Google. This search yielded approximately 3.4 million results. In selecting companies for this study, the first 100 search results that met the following criteria were selected:

1) The company must be a translation agency in the sense that it directly accepts projects from clients and assigns them to translators whose details are maintained on the company's database. This eliminates community or auction sites such as Proz or TranslatorsCafé, which provide a forum for clients and translators to deal directly with each other.

2) The company must not be a sole trader, which means it must be classified legally as some form of company.

3) The company must offer a range of languages, not just one language combination. This helps to increase the likelihood that the company will receive sufficient numbers of speculative applications from prospective freelancers.

4) The company must accept speculative applications from translators (evidenced through the presence of a "careers" or "work with us" page or some other form of registration details for freelancers).

Although no specific regions of the world were targeted, the agencies selected using the above methodology represented a wide geographic area spanning Europe, Asia and North America.

The analysis of the agencies confirmed that there are two key ways in which translators apply for work: completion of a registration form which asks specific questions about a translator's skills and background or submission of a traditional application in which translators have a certain amount of scope in deciding which information to include. This dichotomy can be described as self-identification versus self-description. The forms presented to translators typically contain standard questions relating to 
contact details, rates, experience and qualifications as well as a list of subject specialisms from which translators need to select those options which apply. The process of completing this type of form can be described as self-identification.

The survey also revealed that some registration forms do not provide a list of specific specialisms and translators at all, instead providing text boxes where translators simply describe their specialisms in their own words. Along with traditional forms of application, this can be described as self-description.

\subsubsection{Self-identification versus Self-description}

The analysis of the companies surveyed revealed that $52.3 \%$ of agencies use a list of specialisms as part of their recruitment process (self-identification) whereby translators select those options that match their experience. The remaining $47.7 \%$ of companies either requested a detailed $\mathrm{CV}$ or provided space in the registration form where translators enter their specialisms in free text form (self-description). Of the agencies that do provide a list of specialisms, the number of specialisms can vary from a basic list of roughly 10 or so areas to more lengthy lists of 20 or more separate specialisms or variations.

The challenge posed by self-description, for example, is that translators may not have the vocabulary needed to accurately identify specialist fields. In the absence of suitable terms to describe their specialisms, translators may resort to generic hypernyms in the hope that they will somehow suffice. Alternatively, translators may use terms to describe their specialisms that are not commonly recognised by the wider translation community. Both cases can be problematic if a project manager, searching through a database for translators with specific skills, uses search terms that do not appear in a translator's profile.

While the analysis of websites specifically excluded translator job sites such as Proz.com, Aquarius.net and TranslatorsCafe.com, to completely exclude them from this study would be unwise given the large numbers of translators who use them. While there is widespread criticism of the work practices promoted by these sites and the effects they have on the translation industry and working conditions for translators (see Ricketts 2010), ${ }^{2}$ a significant number of translators rightly or wrongly use these sites to find work. An analysis of these sites shows that translators are again expected to select their specialisms from an extensive list as part of the registration process for all three sites. Proz.com provides a list containing 179 items, while Aquarius.net's list contains 74 items and TranslatorsCafe.com's, 152 items.

Given the similarities, in terms of length, scope and detail, between the lists provided by some of the agencies and the lists provided on the translator forum sites, it is not possible to exclude the possibility that the forum sites are in some way influencing the way in which agencies describe specialisms and recruit translators.

\subsubsection{Observations on Recruitment Practices}

Compiling the various lists of specialisms from each of the websites surveyed including the three translator job sites - produces a rather extensive list comprising 283 distinct specialisms. A combined list of all of the specialisms listed on the various sites is presented in Appendix 1. This list omits identically phrased repetitions, but includes cases where different names appear to be used for the same area or where more comprehensive names are used. 
Despite the large number of detailed specialisms listed, they can, however, be grouped into a relatively small set of generic categories as shown in Figure 1, which illustrates the composition of Appendix 1 on the basis of these categories. One particularly interesting observation to emerge from this analysis is that science and technology account for some $51 \%$ of the specialisms listed with medicine adding a further $8 \%$ to bring the total volume of science and technology-related translation to $59 \%$. This almost exactly corresponds to the figures reported by Boucau (2005), which estimate that science and technology make up $60 \%$ of the total demand for language services.

\section{FIGURE 1}

\section{Classification of Specialisms by Sector}

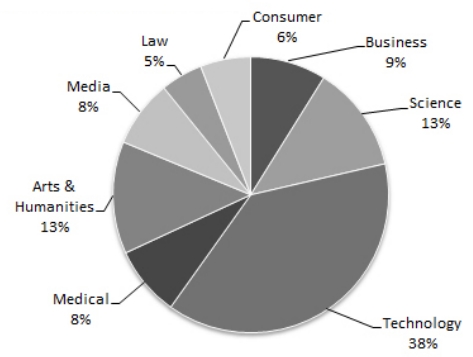

The list of specialisms shows that there is a significant amount of detail in the way specialisms are described. In addition, in certain lists - particularly those from the translator community websites - there is frequently a significant amount of repetition or overlap between separate specialisms. This, together with the variations in the ways the same specialisms are described, has the potential to make the process confusing, time-consuming and stressful for translators, especially novice translators who, because they are only starting out, may not have clearly defined specialisms.

However, irrespective of whether a translator is presented with a lengthy list of specialisms with which they are expected to self-identify or describe their specialisms or a blank box in which to write their specialisms, the challenges presented are the same. Out of all of the myriad possible specialisms, which ones should a translator choose?

The lists of specialisms show a number of things:

1) Translators are expected to have clearly defined specialisms and are expected to be able either to define their abilities in terms of lengthy lists of specialisms or describe their specialisms in their own words.

2) There is an extremely high level of differentiation between specialisms and few, if any, sources describe high-level "generic" specialisms, such as technology, economics or science.

3) The process of finding work requires translators to have a high level of self-awareness of their skills and abilities.

\section{Preparing Translators for Industry}

The issue of specialisms arises frequently in the translation literature but, in many cases, specialisms are dealt with in terms of generic subject groupings, for example 
technical, financial, medical, engineering, or as in the case of Gouadec (2007: 338), in terms of domain knowledge and job types. Although this might seem reasonable, and indeed practical within the constraints of translator training programmes and broad discussions on translator pedagogy, the level of detail demonstrated by the list of specialisms compiled as part of this study clearly shows that newly qualified translators are not necessarily receiving adequate preparation.

It is useful at this point to discuss what we mean when we refer to "specialisms." In the context of this paper, specialising in a particular area involves acquiring both subject knowledge relating to that domain and a knowledge of the language used by experts in that domain. Such a definition is also supported by Kastberg (2009), Bucacek (2001) and Herman (1993) and means that rather than simply concentrating on the linguistic features of texts written in a particular area, we need a solid grasp of the concepts being discussed if we are to fully understand a text for the purposes of translating it. There is little point in knowing a vast amount of specialised words and phrases if we do not know where, when and how to use them. Put simply, if we do not understand what a text is saying, we cannot translate it.

An interesting perspective on the topic of specialisms is provided by Robinson (2003: 128), who argues that translators need not be an expert in a particular area but must be capable of understanding enough of the subject in order to write like an expert. This is echoed by Bucacek, who states that a specialism does not "necessarily mean that the translator has to be an "expert" in the field, but to a significant degree, the translator needs to have acquired knowledge of the field through schooling, work experience, and self-study" (Bucacek 2001: 7).

\subsection{Developing Specialisms}

Since translators are rarely trained on the basis of their previous specialism in a subject field, but are expected to develop subject specialisms later, they need to have the means to cope with unfamiliar subjects and the techniques of producing reliable work despite their limitations of knowledge. (Nkwenti-Azeh 2001: 619)

While in an ideal world we might want translators to have some form of dual qualification in both translation and their specialist area (see, for example, Fluck 1992: 221; Samuelsson-Brown 2004: xi), the reality is that this is simply not practical for reasons of cost and time. Indeed, as Kastberg (2009: 88) points out, in some countries the process of gaining a qualification in translation and a qualification in some other specialist field could take anywhere between 8 and 10 years. For this reason, Samuelsson-Brown (2004: 8) suggests that we should work on the assumption that translators are linguists first and experts second.

Clearly, this generalisation does not take into account those translators who trained to be translators as mature students having done some other job first. Nor does it take into account those translators who have a specialist qualification, but no translation qualification. Nevertheless, we can assume that in the vast majority of cases, Samuelsson-Brown's position is correct, and that we should focus on the development of specialisms in the context of translator training programmes.

The analysis of recruitment practices makes it clear that more than half of all translation agencies expect translators to be able to identify themselves using a list 
of specific and clearly defined specialisms, while the remainder expect translators to know how to describe their abilities in their own words. But how do we help novice translators identify and describe their specialisms? Furthermore, if, like any other profession, translators' jobs evolve over time, how do we prepare them for future changes in their roles and specialisms? Can students be taught to "future-proof" their specialisms?

For trainers, it has long been acknowledged that the design of training curricula needs to incorporate professional competences ${ }^{3}$ (see Hurtado Albir 1999: 34 and Kelly 2005: 17). In general, this relates to professional practices involving the use of IT tools, negotiation skills and exposure to realistic texts (see Galán-Mañas 2011), as well as standard working practices such as team-work, and so on. However, the PACTE group (2005) also recognises specialist knowledge as an extra-linguistic subcompetence that translators need to possess. Similarly, the European Master's in Translation Expert Group identifies the need for translators to learn how to develop specialist knowledge (EMT Expert Group 2009: 7), ${ }^{4}$ although it does not say how this should be achieved. While we can use a range of realistic texts in class and get students to work in teams to perform a variety of different professional tasks, this presupposes novice translators being able to find work in the first place. If students do not have sufficiently defined specialisms that are in demand on the market, such efforts, while important, may be largely ineffectual.

The standard way of helping students to develop specialisms is through the choice of texts used in translation classes. The usefulness of this approach cannot be denied, but its effectiveness is limited somewhat by what can reasonably be accommodated in the timetable and by the background of the individual trainer. An alternative solution is to incorporate additional courses that teach domain-specific knowledge. This approach is in use at various institutions, but again, is limited by what can realistically be accommodated within a training programme given timetable constraints and the overall credit requirements of the programme. This difficulty is recognised by Nord (1996: 316), who expresses concern at how these additional courses are coordinated or integrated into the broader translator-training programme. Other approaches, such as that proposed by Maher, Waller et al. (2008), involve the use of corpora consisting of authentic texts from a particular subject area. Although useful, such an approach has a number of limitations. Firstly, it emphasises the acquisition of linguistic knowledge of the specialist area with no guarantees that this will necessarily be accompanied by subject knowledge. Secondly, the time and resources required to develop these resources and to learn from them may be prohibitive.

It is clear, however, that we cannot train translators for every eventuality (see Nord 1996) or expect translators themselves to engage in independent learning in a separate discipline as suggested by Samuelsson-Brown (2004) because of the time and expenses involved (Kastberg 2009; Fluck 1992). Nor is it realistic to expect trainers to provide students with anything other than a small representative subset of the specialisms contained in these lists. Indeed, it has even been suggested that we should not even attempt to train students for highly specialised markets, as these may change - or even disappear - by the time students enter the labour market (Aula.int 2005: 136). We can, however, give them the tools to deal with the issue of specialisms within the typical context of their training programmes and experience. 
Translator training should also include issues such as career planning and client management. Such an approach is outlined by Gertrude Champe in her Letter to a Young Translator (2001) who urges an aspiring young translator to take a proactive approach to career planning, particularly with regard to specialisms. Indeed, she urges the translator to start early and actively seek out ways of adding new areas of knowledge while studying at university. Echoing Kiraly's position that "education should realistically reflect actual practice with respect to the tools, methods and procedures of the profession with which students are becoming acquainted" (Kiraly 2000: 123), Byrne (2003) also stresses the need for students to learn how to create their own jobs. While the approach described, which involves preparing them for the reality of freelance translation through a prototypical professionalization module, may not be practical in all learning environments, the idea of equipping students with the necessary transferrable skills to be able to take ownership of their career and its development is still useful nonetheless.

With this in mind, the following section outlines a framework that can be used by students and translators to identify, categorise and target specialisms as part of their (ongoing) professional development.

\section{Framework of Specialisms}

\subsection{Initial Specialisms}

At the start of their careers, new translators may simply shrug when asked to provide details of their specialisms, saying that they do not have any yet. This is understandable since, having studied translation as their first degree, all they know is translation. They may not have had the opportunity to study anything else, either before or during their translation studies, and they may have dealt only with general texts in translation classes. In such cases, the options open to translators are:

1) say that they do not have any specialisms and risk not getting any work, or at best appearing unprofessional;

2) lie about their background and fabricate specialisms in the hope that they can learn enough about the topic before they are found out;

3) carry out a self-assessment and identify the things they are good at.

Initial specialisms are those innate areas of detailed knowledge that most, if not all, people have whether as a result of conscious study, hobbies, work or some other activity. They are identified using some form of skills audit that allows students to reflect upon their abilities and knowledge at any given time. As trainers, we can support this reflection process by discussing students' backgrounds, identifying interests and exploring related areas. In the case of longer programmes of study, we can also use a variety of different texts and subjects to identify in which areas students appear to have a natural ability. There are two implications of identifying these initial specialisms. For the translator, it creates a level of self-awareness necessary for completing job applications. For trainers, it provides us with a clear starting point from which to begin training.

Students should be encouraged to reflect upon their learning and experiences to date. For example, which subjects did they study at second level? Did they take any additional classes at university? Do they have any special interests or hobbies? Did 
they choose a particular area or text type for their dissertations? Have they produced extended translations or translation portfolios?

\subsection{Organic Specialisms}

Organic specialisms are specialisms that emerge naturally out of existing specialisms. They can be specialisms in cognate areas that the translator develops, or they may arise spontaneously as a result of receiving translation projects in related areas. For example, a translator with an initial specialism in biology might branch out into areas such as pharmaceuticals, nutrition, medical devices and even sports goods. Similarly, a translator who specialises in journalistic texts might find the transition to marketing and advertising texts relatively easy and may move into these areas with minimum effort. Initial specialisms in mechanical engineering might lead on to specialisms in transport, construction, medical devices or industrial process controls.

As trainers, we can encourage this process by providing a range of texts in cognate areas to give students as wide as base of initial specialisms as possible.

\subsection{De Facto (or Imposed) Specialisms}

De facto specialisms are specialisations that come about by virtue of a translator's job or the type of project a translator receives on a regular basis from an agency (see Samuelsson-Brown 2004: 60). In other words, they are imposed on the translator as a result of their environment, whether this is their job description or the prevailing market conditions. Although this type of specialism is not something that a translator can always have full control over, there is a responsibility on the part of trainers to prepare students for likely de facto specialisms. For example, if the vast majority of jobs for graduates in a particular market are in an area such as mechanical engineering, then it behoves us to provide a basis for this in class.

\subsection{Strategic (or Targeted) Specialisms}

Strategic specialisms are specialisms that translators specifically set out to acquire as a way of broadening their current skills. This may be because a translator does not have a satisfactory amount of initial specialisms or it may be as part of an on-going process of professional development. On-going professional development is essential for translators to ensure that they remain an attractive and useful translation option for clients, particularly since certain specialisms have a natural shelf life and will eventually become outdated.

Much like the coopers of old who saw their entire profession disappear when manufacturers began to make barrels from metal, it is inevitable that some of a translator's specialisms will become obsolete and simply cease to be in demand. Translators may very well experience considerable hardship if the bulk of their work that comes about as a result of specialist expertise in a particular technology suddenly dries up because a new technology has emerged to replace it. It is for this very reason that Gouadec suggests that "it is good practise to select two or three technical areas, rather than just one highly specialised field, just in case the market in that particular area suddenly collapses" (2007: 209). 
As trainers, we can encourage students to identify new specialisms based on predicted market needs (which can be elicited from newspaper reports, etc.), case studies and/or their own personal interests and aptitudes.

To start with, it is necessary to identify which areas can be developed as specialisms, and then devise a plan for achieving it. Using specific companies or types of company, students can analyse their requirements on the basis of their primary and secondary areas of activity. So, for example, if a company designs software, they will clearly need translators with expertise in IT, software and networking. But they might also need translators who can deal with contracts and licence agreements, empirical studies and knowledge relating to the specific industry where the software will be used.

Similarly, a client involved in real estate will probably need a translator who can cope with texts relating to finance, utilities, renewable resources, transport, interior design, advertising and construction, while a company that makes tyres will need translators who can translate texts on chemistry, automotive engineering, law, marketing, journalism, business and finance.

The key questions that translators need to ask when identifying and targeting strategic specialisms include:

- In what other areas are your current/prospective clients involved?

- Can your skills be applied elsewhere?

- What subjects are related to your current knowledge?

\section{Implementing the Framework}

The most important aspect of the framework is that it should create some form of opportunity for reflection, which allows students to take ownership of their career development. This is the key strength of the framework, and it should be supported wherever possible. The purpose of this framework is to help students to identify what they already have in terms of specialisms, where they can go from there and how they can identify and develop additional specialisms. When applied as part of a translator's training, the framework helps students to reflect upon their skills and formulate a clear plan for developing them. It can also be used on an ongoing basis by translators as part of their continuing professional development.

\subsection{Personal Development Portfolios}

In 1997, the National Committee of Inquiry into Higher Education, known informally as the Dearing Report, produced a series of reports into the future of higher education in the United Kingdom. Of the 93 recommendations made by the committee, Recommendation 20 states that training institutions should provide "a means by which students can monitor, build and reflect upon their personal development" (Dearing 1997). ${ }^{5}$ Much work has been done since then by the Quality Assurance Agency for Higher Education (QAA) to implement this recommendation in the form of Personal Development Planning, the aim of which is to help students to

[...] plan, integrate and take responsibility for their personal, career and academic development, identifying learning opportunities within their own academic programmes and extra-curricular activities. (QAA 2011: 56) ${ }^{6}$ 
This process typically involves students preparing a Personal Development Portfolio (PDP), and is widely used by third level institutions in the UK. Such portfolios generally take the form of a template that is provided to students at the start of their programme or course, and it is used to allow them to record their personal growth and successes, reflect on their achievements, state their objectives, and plan the actions required to meet them. PDPs are sometimes administered as part of a department's personal tutoring system (QAA 2011: 17-19) whereby the reflection is not linked to any one specific module, but rather to the overall programme of study.

For the purposes of implementing the framework of specialisms, the portfolios, however, can be administered by teaching staff on individual translation modules. The QAA also maintains that student engagement tends to be higher where PDPs are assessed, although this is not a prerequisite for their use (QAA 2011: 42-46, 84).

Given the emphasis on reflection, planning and extracurricular learning opportunities, the PDP model is ideally suited to implementing the framework of specialisms. In addition to its overall effectiveness in terms of student learning, the PDP framework provides a relatively simple, low-cost and easy-to-manage mechanism for achieving learning objectives.

Once they have received an introduction to the PDP process explaining the rationale and the methodology for its use, students can be provided with a template with which to create their portfolio. The template can be designed flexibly to match the particular learning environment, but it should at the very least provide students with an opportunity to address the following issues:

- What are my current areas of expertise?

- What is my current level of knowledge in each of these areas?

- Can my current knowledge be applied to other areas?

- What specialisms are most in demand in my particular market?

- Which companies are the main employers in my market?

- What subject areas do they rely on?

- What are the main growth areas nationally and internationally?

- What new knowledge do I need to learn in order to specialise in this area?

- How will I go about acquiring this new knowledge?

- What opportunities do I have to take part in additional, extracurricular learning activities?

In the case of initial specialisms, the form should provide space for each type of specialism and details of how it has been gained as well as the extent of the specialism (for example, basic, intermediate, advanced). Once the initial assessment has been done to identify the initial specialisms, trainers can help by providing additional opportunities in class for students to add to the list of specialisms on their portfolios. This can be done, for instance, by preparing them for likely de facto specialisms. Students can then apply the rest of the framework over the course of their studies. If necessary, trainers can provide help by conducting analyses or providing pointers for strategic specialisms. If the PDP process is administered by personal tutors, it is essential that this information is passed on to individual members of teaching staff to ensure this information is properly utilised. 


\subsubsection{Suggestions for Implementing PDP}

When it comes to implementing this framework in a training programme using the PDP model, there is an enormous amount of flexibility as to the specific amount of contact time and trainer involvement. Nevertheless, given that the framework is intended to be used as a reflective tool, it is advisable that it be used over a relatively long timescale.

Ideally, an introductory workshop should be carried out at the start of a programme to explain the principles behind the framework and to help students conduct an analysis of their initial specialisms. Beyond the introductory workshop, trainers then have the option of organising further workshops at regular intervals, for example, at the end of each semester or academic year, or asking students to submit their portfolios to individual tutors or to programme leaders for feedback. Irrespective of which option is chosen, placing the onus on students to continually update their portfolios allows them to monitor their progress and may help motivate them to play a more active role in their learning.

However, perhaps the most beneficial time to implement the framework is towards the end of a training programme, when students should be thinking about their career options and making preparations to find employment. A final workshop can be organised early in the final semester with the aim of helping students to compile a finalised list of their specialisms. The results of this final workshop can then be used by students when drafting CVs, job applications and personal websites.

An interesting aspect of PDPs is that they are intended to be used to promote lifelong learning, which means translators can use them repeatedly, even after they have entered the workplace, as a way of monitoring and developing their skills. From this point of view, the specialisms framework can be applied as part of a translators' continuing professional development.

\section{Conclusions}

From the preceding paragraphs it is clear that there is substantial demand for specialised translators. The notion of the "generalist" translator does not appear to be realistic given the scope and detail of specialisms listed in the registration forms used by translation agencies. The survey shows that translators seeking to work with agencies must have a clear awareness of their own expertise and abilities. Even where translators do not need to self-identify using lists of specialisms, they are still expected to have the necessary terminology to clearly describe their specialisms in job applications.

It is clear that it is essential to prepare students for the huge range of specialisms with which they will be asked to identify. But while it is not possible to provide students with training in every specialist area, we need to teach them how to adapt to changing market conditions.

The framework presented in this paper takes into account the limited possibilities for developing wide-ranging specialisms in translator training programmes. It provides a flexible mechanism whereby translators and trainers can adapt and customise learning strategies to suit their particular needs and interests.

The framework, when implemented using method such as Personal Development Planning or reflective journals, provides students with a means of playing a direct 
part in shaping their education and will help them take the first steps in identifying and devising strategic targets for the on-going career development.

\section{NOTES}

1. Beninatto, Renato S. and Kelly, Nataly (2009): Ranking of Top 30 Language Services Companies. Common Sense Advisory. Visited on 1 February 2012, <http://www.commonsenseadvisory.com/ Research/All_Users/090513_QT_2009_top_30_lsps/tabid/1692/Default.aspx?zoom_ highlight=ranking $>$.

2. Ricketts, Wendell (2010): The Revolution of the Translators - It's My Business, and I'm Minding It. Visited on 17 April 2014, < http://nopeanuts.wordpress.com/resistance/ministero_di_turismo/ my-business/>.

3. The need to address professionalization issues is also recognised on a European level by the Bologna Process (Conference of European Ministers Responsible for Higher Education, 2009) and nationally, for example, by the Dearing Report in the UK (Dearing 1997, see note 5).

4. EMT Expert Group (2009): Competences for Professional Translators, Experts in Multilingual and Multimedia Communication. DG Translation. European Commission Website. Visited on 5 June 2012, <http://ec.europa.eu/dgs/translation/programmes/emt/key_documents/emt_competences_ translators_en.pdf>.

5. Dearing, Ron (1997): Report of the National Committee of Inquiry into Higher Education. The National Committee of Inquiry into Education. Visited on 15 January 2012, <http://www.leeds. ac.uk/educol/ncihe/>.

6. QAA (2011): A toolkit for enhancing personal development planning strategy, policy and practice in higher education institutions. $2^{\text {nd }} \mathrm{ed}$. Quality Assurance Agency for Higher Education, UK. Visited on 14 April 2014, <http://www.qaa.ac.uk/Publications/InformationAndGuidance/Documents/ PDP\%20Toolkit\%20revised\%202011.pdf $>$.

\section{REFERENCES}

Aula.int (2005): Translator Training and Modern Market Demands. Perspectives: Studies in Translatology. 13(2):132-142.

Boucau, Fernand (2005): The European Translation Industry: Facing The Future. Brussels: European Union of Associations of Translation Companies.

BucaceK, John (2001): An Introduction to Translation. In: Sandra Burns-Thomson, ed. Getting Started: A Newcomer's Guide to Translation and Interpretation. Alexandria: American Translators Association, 5-13.

Byrne, Jody (2003): Freelance Translation: Teaching Students to Create Their Own Jobs. In: Daniel Gouadec and Daniel Toudic, eds. Traduction, Terminologie, Rédaction. Paris: La Maison du Dictionnaire, 161-174.

Byrne, Jody (2012): Scientific and Technical Translation Explained: A Nuts and Bolts Guide for Beginners. Manchester/Northampton: St. Jerome Publishing.

Champe, Gertrude (2001): Letter to a Young Translator. In: Sandra Burns-Thomson, ed. Getting Started: A Newcomer's Guide to Translation and Interpretation. Alexandria: American Translators Association, 16-17.

FLUCK, Hans-Rüdiger (1992): Didaktik der Fachsprachen. Tübingen: Gunter Narr Verlag.

GaLÁn-Mañas Anabel (2011): Translating authentic technical documents in specialised translation classes. The Journal of Specialised Translation. 16:109-125.

Gouadec, Daniel (2007): Translation as a Profession. Amsterdam/Philadelphia: John Benjamins. Herman, Mark (1993): Technical Translation Style: Clarity, Concision, Correctness. In: Sue Ellen Wright and Lelan D. Wright, eds. Scientific and Technical Translation. Amsterdam/ Philadelphia: John Benjamins, 11-20.

Hurtado Albir, Amparo (1999): Enseñar a traducir. Metodología en la formación de traductores e intérpretes. Col. Investigación didáctica. Madrid: Edelsa.

Kastberg, Peter (2009): Personal knowledge management in the training of non-literary translators. The Journal of Specialised Translation. 11:88-101. 
KeLLY, Dorothy (2005): A handbook for translator trainers. A guide to reflective practice. Manchester/Northampton: St. Jerome Publishing.

Kiraly, Don (2000): A Social Constructivist Approach to Translator Education: Empowerment from Theory to Practice. Manchester/Northampton: St. Jerome Publishing.

Lindemuth Bodeux, Eve (2001): 10 Top Tips for a Top-notch Translation Resumé. In: Sandra Burns-Thomson, ed. Getting Started: A Newcomer's Guide to Translation and Interpretation. Alexandria: American Translators Association, 41-42.

Maher, Ailish, Waller, Stephen and Kerans, Mary Ellen (2008): Acquiring or enhancing a translation specialism: the monolingual corpus-guided approach. The Journal of Specialised Translation. 10:56-75.

Nkwenti-Azeh, Blaise (2001): Terminology. In: Sin-Wai Chan and David E. Pollard, eds. An Encyclopaedia of Translation. Hong Kong: The Chinese University of Hong Kong, 610-627.

Nord, Christiane (1996): Wer nimmt mal den ersten Satz? Überlegungen zu neuen Arbeitsformen im Übersetzerunterricht. In: Angelika Lauer, Heidrun Gerzymisch-Arbogast, Johann HALLER et al., eds. Übersetzungswissenschaft im Umbruch. Festschrift für Wolfram Wilss zum 70. Geburtstag. Tübingen: Gunter Narr Verlag, 313-327.

PACTE (2005): Investigating Translation Competence: Conceptual and Methodological Issues. Meta. 50(2):609-619.

RoBinson, Douglas (2003): Becoming a Translator. London: Routledge.

Samuelsson-Brown, Geoffrey (2004): A Practical Guide for Translators. Topics in Translation 25. Clevedon: Multilingual Matters. 
APPENDICES

\section{Appendix 1: List of Translator Specialisms}

Accounting

Acting and Directing

Advertising

Aerospace/Aviation/Space

Agriculture

Agronomy and Crop Science

Aircraft/Aviation

Anatomy

Animal Husbandry = Livestock

Animal Sciences

Anthropology

Applied Mathematics

Aquaculture

Archaeology

Architecture

Arts \& Crafts, Painting

Art/Literary

Arts and Humanities (general)

Astronomy, Astrophysics \& Space

Atmospheric Sciences and Meteorology

Audit $=$ Finance

Automation \& Robotics

Automotive/Cars \& Trucks

Banking and Financial

Bible and Biblical Studies

Biochemistry

Bioengineering and Biomedical Engineering

Biology (-tech, -chem, micro-)

Biomedical

Biometrics

Biophysics

Biopsychology

Biostatistics

Biotechnology

Botany

Broadcast Journalism

Building \& Construction

Bus/Financial

Business (general)

Business Administration and Management

Business Marketing

Cars $=$ Auto

Cartography

Ceramics $=$ Materials

Ceramics Arts and Ceramics

Certificates, Diplomas, Licenses, CVs

Chemistry, Chemical Technology and Related Industries

Child Care

Children's Literature $=$ Poetry \& Literature
Cinema, Film, TV, Drama

Civil Engineering

Clothing $=$ Textiles

Communications $=$ Telecommunications

Computer and Information Sciences

Computer Engineering

Computer Games and Gambling, Electronic Games, Games of Chance

Computer Hardware

Computer Systems Analysis

Computers (general)

Computers: Software

Computers: Systems, Networks

Construction/Civil Engineering

Contracts

Cooking/Culinary

Copywriting

Corporate Law

Cosmetics

Cosmetics, Beauty

Criminology

Culinary Arts

Data Communications

Data Processing

Dentistry

Design and Applied Arts

Desktop Publishing (DTP)

DVDs $=$ Media

Ecology \& Environment

Ecology

Economics

Education/Pedagogy

Electrical Engineering

Electronics

Energy/Power Generation

Engineering (general)

Engineering: Aero $=$ Aerospace

Engineering: Chem $=$ Chemistry

Engineering: Civil \& Hydraulic

Engineering: Civil = Construction

Engineering: Electrical $=$ Electronics

Engineering: General

Engineering: Industrial

Engineering: Mechanical

Engineering: Nuclear

Engineering: Petroleum

Entomology

Entrepreneurship

Environment \& Ecology

Esoteric practices
Ethnic and Cultural Studies

European Union

Fashion $=$ Textiles

Fibre, Textile and Weaving

Fiction $=$ Poetry \& Literature

Film \& Television

Film \& TV = Cinema

Film and Cinema Studies

Finance \& Economics (general)

Financial Markets $=$ Finance

Fire Protection

Fishing and Fisheries Sciences

Folklore

Food \& Dairy

Forensic Science

Forestry/Wood/Timber

Furniture/Household Appliances

Games/Video Games/Gaming/ Casino

Gastronomy

Gastronomy $=$ Cooking $/$ Culinary

Gems, Precious Stones, Metals $=$ Mining

Genealogy/Family History Research

General/Conversation/ Greetings/Letters

Genetics

Geochemistry

Geography

Geology

Geophysics and Seismology

Gerontology

Glass $=$ Materials

Government/Politics

Graphic Arts = Photo/Imaging

Health Care $=$ Med: HC

Heating, Air Condition and Refrigeration

History

Hospitality \& Tourism

Human Resources

Humanities and Humanistic Studies

Idioms/Maxims/Sayings

Industry and Technology (general)

Information Sciences and Systems

Insurance

International Org/Dev/Coop

Internet

Internet, e-Commerce

Investment/Securities

Iron \& Steel $=$ Metallurgy 
Islamic Studies

IT (Information Technology)

Journalism and Mass

Communication

Labour = Human Resources

Land $=$ Real Estate

Law (general)

Law/Patents

Law: Contracts

Law: Patents, Trademarks, Copyright

Law: Taxation \& Customs

Leisure $=$ Tourism

Linguistics

Literature $=$ Poetry \& Literature

Livestock/Animal Husbandry

Logistics $=$ Transport

Machinery \& Tools

Management

Manufacturing (Metal

Working and Products, Instruments, Furniture,

Printing, Clothing, etc.)

Marine and Aquatic Biology

Maritime $=$ Ships

Marketing/Market Research

Materials (Plastics, Ceramics, etc.)

Mathematics \& Statistics

Mechanical Engineering

Media/Multimedia

Medical (general)

Medical Instruments

Medical: Cardiology

Medical: Dentistry

Medical: Health Care

Medical: Instruments

Medical: Pharmaceuticals

Medicine - Acupuncture and Oriental Medicine

Medicine - Medical Technology

Medicine - Microbiology and Bacteriology

Medicine - Neuroscience

Medicine - Nursing

Medicine - Occupational Health and Industrial Hygiene

Medicine - Ophthalmology

Medicine - Pharmacology

Medicine - Psychiatry

Medicine - Public Health

Education and Promotion

Medicine - Social Psychology
Medicine - Toxicology

Medieval and Renaissance Studies

Metallurgical Engineering

Metallurgy/Casting

Meteorology

Metrology

Military/Defence

Mining \& Minerals/Gems

Mining \& Minerals

Mining and Petroleum Technology

Molecular Biology

Multimedia

Multimedia $=$ Media

Music

Music History and Literature

Names (personal, company)

Naval Architecture And Marine Engineering

Networking $=$ Computers: Networking

Nuclear Engineering

Nutrition

Oceanography

Oil \& Gas = Petroleum

Oil and Gas Engineering

Optics

Organic Chemistry

Other

Paper/Paper Manufacturing

Patent Translation

Patents

Patents = Law: Patents

Patents, Trademarks \& Copyrights

Pedagogy = Education

Petrochemistry

Petroleum Engineering

Pharmaceutical

Philosophy

Photography/Imaging ( $\&$ Graphic Arts)

Physical and Theoretical Chemistry

Physical Education Teaching and Coaching

Physics

Plants $=$ Botany

Plastic $=$ Materials

Poetry \& Literature

Political Science/Government

Polymer Chemistry

Power $=$ Energy

Printing \& Publishing

Psychology
Public relations $=$ Advertising

Radiation Biology

Radio and Television

Broadcasting

Real Estate

Religion

Retail

Robotics = Automation \& Robotics

Rubber $=$ Materials

Sailing $=$ Ships

SAP

Science (general)

Shipping \& Maritime

Ships, Sailing, Maritime

Slang

Social Science, Sociology, Ethics, etc.

Sociology

Software $=$ Computers: Software

Software Engineering

Software Localization

Sport and Fitness

Sports

Sports/Fitness/Recreation

Statistics $=$ Mathematics

Surveying

Symbols/Abbreviations/ Acronyms $=$ General

Tax Law

Tech/Engineering

Telecom(munications)

Textile Sciences and

Engineering

Textiles/Clothing/Fashion

Theatre

Theology and Theological Studies

Theoretical and Mathematical Physics

Tourism \& Travel

Trains $=$ Transportation

Transport/Transportation/ Shipping

Transportation

Veterinary $=$ Livestock

Veterinary

Video editing/DVDs $=$ Media

Video Games $=$ Games

Visual and Performing Arts

Wine/Oenology/Viticulture

Women Studies

Wood $=$ Materials

Wood Industry = Forestry

Zoology 